\title{
DESCAMINHOS DO COLECIONISMO
}

Ubiratan Machado

Antes de falar um pouco de meus livros, das pequenas aventuras para adquiri-los e de minha condição de aprendiz de bibliófilo, gostaria de abordar alguns aspectos relacionados à bibliofilia - uns históricos e outros atuais - sendo que estes incomodam todos os amigos do livro.

Ao ser convidado para participar deste seminário, a primeira coisa que pensei foi no futuro do livro e, em consequência, da bibliofilia neste mundo pós-moderno, cada vez mais massificado e automatizado, em plena agonia do humanismo - se é que ele já não morreu e se esqueceram de me avisar -, onde a internet é o lar virtual de todos nós, excelente fonte de consulta, uma conquista admirável da humanidade, mas estranha à arte de pensar, mundo no qual as pessoas estão perdendo o gosto pelo sutil prazer de conversar e no qual a cada dia parece - parece - diminuir o prestígio e a influência do livro.

Essas são indicações sumárias do presente, base de especulação dos estudiosos do futuro, que preveem uma sociedade sem livros físicos para breve - se bem que este em breve está se alongando muito, pois o assunto vem sendo enfatizado, pelo menos, desde a década de 1980. E se voltarmos mais no tempo, desde os anos 1860 (Machado de Assis 
previa a morte do livro, absorvido pelo jornal; uma teoria da época do filósofo francês Éugene Pelletan). Os curiosos de futurologia sabem que a sondagem do futuro, apoiada em dados da realidade atual, pode ser correta em pequenos detalhes, mas sempre falha quando se trata de uma visão abrangente da sociedade. Nos deslumbrados anos 1950 e nas décadas seguintes, surgiram muitos exercícios de futurologia, elaborados por profetas intuitivos, isto é, supostamente dotados de dons paranormais (característica do grande Júlio Verne), e de profetas tecnocratas, que esboçavam o porvir apoiados em tendências da realidade social e econômica da época, da tecnologia disponível e no que essa tecnologia anunciava como conquistas futuras. Um desses profetas, misto de economista e tecnocrata, tornou-se famoso em todo o mundo com suas previsões "rigorosamente científicas”. Chamava-se Hermman Kahn, era norte-americano e, com toda a sua parafernália de dados e conhecimentos tecnológicos e científicos, acertou menos que um profeta de roça. Como seus colegas de ofício, previu algumas coisas óbvias; mal comparando, como o sujeito que prevê que a gata prenha vai ter uma ninhada de gatinhos. Coisas de somenos. Mas ninguém previu a eclosão da informática - apesar dos computadores já existirem - e a revolução que ela provocou na sociedade, só comparável à grande renovação espiritual e cultural do Renascimento, com o surgimento da imprensa.

A crise do livro, a meu ver, se assemelha à morte anunciada do teatro, quando do surgimento do rádio e depois da televisão. Houve uma crise teatral, mas logo a estabilidade voltou, adaptada a uma nova realidade social. O mesmo ocorre com o livro impresso e o ebook, que cresceu muito e agora se estabilizou, enquanto o seu concorrente permanece, vencendo, com galhardia, este primeiro round.

A questão, me parece, deve ser colocada da seguinte forma: vai diminuir o público do livro impresso? Inevitável. É um fenômeno que já ocorre, inclusive por pressões e características da vida moderna; a pressa excessiva; a disponibilidade cada vez menor de tempo; os meios de comunicação imediata, como o celular e outras ferramentas mais modernas de comunicação; e outras características dessa nossa civilização do espetáculo, como a definiu Vargas Llosa, na qual as pessoas têm pavor da vida interior e se empenham na busca desesperada da fama a todo custo (os famosos quinze minutos de fama). Ora, livro e leitura são o oposto do espetáculo, e se há espetáculo ele se desenrola no interior de cada um, na sua cachola.

Assim, na certeza de que os profetas tecnocratas erram sempre, podemos nos tranquilizar, mandar eles passearem no bosque e comemorar a vitalidade do livro físico e da bibliofilia, uma atividade quase tão antiga quanto a palavra escrita, que em sua longa trajetória, despertou 


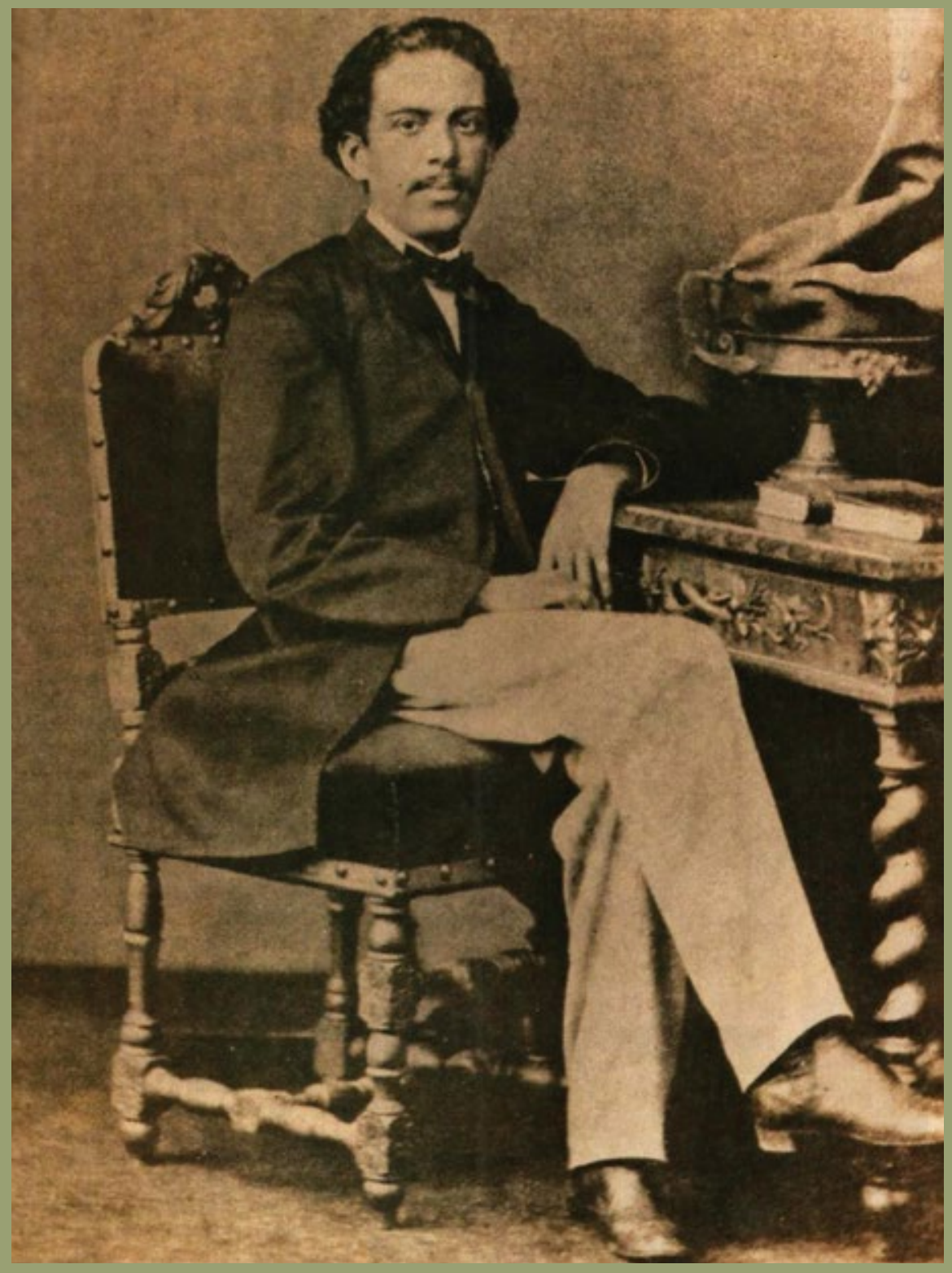

Na juventude, Machado de Assis admitia

a morte do livro, absorvido pelo jornal. 
muitos equívocos, despeitos, zombaria, mas também louvores e declarações de amor, contando até com a proteção dos céus.

Pois, como toda atividade nobre, os bibliófilos têm um padroeiro aliás, padroeira - dadivosa e elevada na hierarquia celeste. Chama-se Santa Wilborada. No ano de 925, a Abadia de Saint Gall estava ameaçada pelos invasores bárbaros que, como era seu costume, ameaçavam queimar tudo. Seria o fim da riquíssima biblioteca, formada por milhares de volumes. Contam as crônicas da época que Wilborada, uma espécie de bibliotecária da casa, enterrou os livros após uma visão. Os bárbaros foram repelidos, mas o mosteiro ardeu como o pavio de uma vela. O corpo da monja, mutilado e desfigurado, foi abandonado em uma pequena elevação, onde mais tarde encontraram os livros intactos. Outra versão, menos romântica, diz que os livros foram transferidos para um mosteiro próximo e que Wilborada morreu com um machado cravado na cabeça, sendo por isso representada pela Igreja com um livro na mão direita e um machado na esquerda. Seja como for, pelo seu heroísmo ela ascendeu à santidade. Como padroeira dos bibliófilos, possivelmente protege-os dos amigos do alheio, do olho gordo dos colegas e, sobretudo, dos chatos que insistem em pedir livros emprestados.

Longe dos céus, no plano material, se fosse preciso escolher um patrono dos bibliófilos, o eleito não poderia ser outro senão o velho Anatole France. Ninguém amou os livros com tanta ternura e nem os exaltou com tanta dignidade e bom humor quanto ele, na vida e em sua obra. Livros e bibliotecas estão sempre presentes em seus romances e contos, por vezes de forma insólita, como aquela biblioteca de A Revolta dos Anjos, que mantinha relações mágicas com o além. E, curiosamente, entre os muitos autores que abordaram o tema da bibliofilia em prosa de ficção, ele foi o único - pelo menos até onde vai meu limitado conhecimento - no qual o impulso humanitário supera a paixão do colecionador. O romance O Crime de Silvestre Bonnard conta a história de um bibliófilo a quem nada mais interessava no mundo a não ser os livros - a sua "cidade dos livros", como ele a chamava que resolve vender sua biblioteca para beneficiar o futuro de uma órfã. Mas, à noite, ele acorda, "furta" e esconde um dos livros, "o tesouro com que havia sonhado toda a noite". Foi esse o crime inocente de Silvestre Bonnard.

A tradição literária sempre mostrou o contrário: o apaixonado pelo livro como uma espécie de sultão em seu serralho, na comparação pitoresca de Eduardo Frieiro, capaz de todas as extravagâncias para guardar seu tesouro ou desfrutar do famigerado exemplar único. É o tema daquele conto da mocidade de Flaubert, intitulado Bibliomania. Após penetrar numa casa em chamas e se apossar de uma Bíblia - 


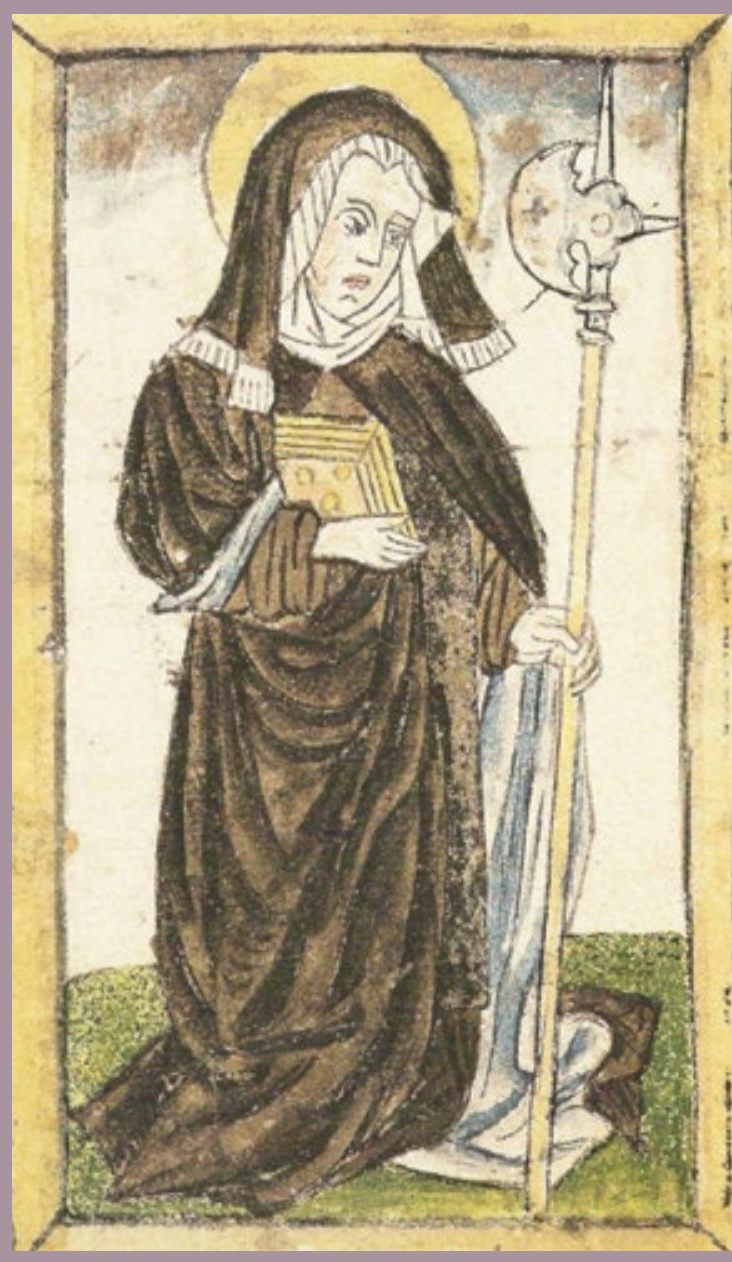

Santa Wilborada,

padroeira dos bibliófilos.

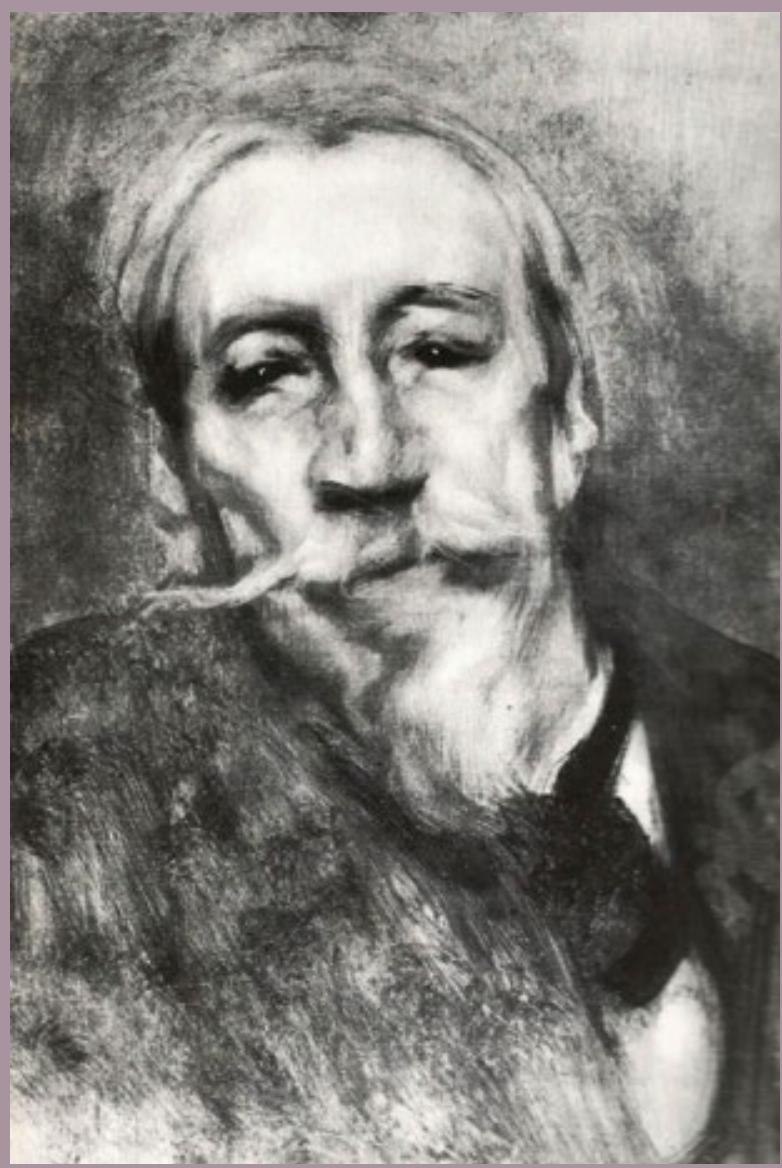


primeiro livro impresso na Espanha -, o livreiro Giacomo é preso, sob acusação injusta de atear o incêndio para se apossar daquele exemplar único, e condenado à morte. Seu advogado de defesa desmente essa versão, apresentando outro exemplar do livro. Então, Giacomo, num impulso delirante, avança para ele, se apossa da Bíblia e a rasga, a fim de continuar sendo o dono do exemplar único, mesmo que isso lhe custasse a vida.

Essa atitude alucinada de alguns maníacos acabou sendo atribuída a todos os bibliófilos, em paralelo à tradição várias vezes milenar do livro como fonte de enriquecimento espiritual e, por osmose, de aprimoramento social. Creio que a mais antiga declaração de amor ao livro é do faraó egípcio Ramsés II - lá se vão mais de três mil anos -, talvez o primeiro bibliófilo do mundo, que escreveu à porta de entrada de sua biblioteca, em Tebas, "Remédio dos males da alma". O acesso a esse remédio foi interrompido no período medieval com a destruição das bibliotecas pagãs pelos cristãos, a ignorância brutal e generalizada dos senhores feudais e o confinamento dos livros em mosteiros. Só no Renascimento, com a difusão do papel e o vento de inteligência e libertação que soprou no espírito do homem ocidental, os livros começam a circular no mundo laico. Ainda assim, até o século XVIII as bibliotecas particulares são escassas, com número limitado de exemplares e, em geral, propriedade de reis, nobres e pessoas da corte.

No século XIX, quando o acesso ao livro se democratizou, surgiram as grandes bibliotecas privadas e, desde logo, reapareceram com ímpeto os colecionadores seletos e compulsivos, em geral gente de posses, pois o preço do livro ainda era elevado, mas também pessoas de recursos modestos, mas astutas na arte de garimpar livros. O povo desconhecia estes e só via a atividade dos ricos. Dessa forma, o termo bibliófilo ganhou um sentido enganoso, que persiste ao longo do tempo, significando um nababo, vivendo numa mansão onde fios de ouro pendem do teto, a biblioteca cheia de incunábulos, edições de vinte, cinquenta, cem exemplares, ilustradas por Picasso, Dalí, Picabia, autógrafos de Voltaire, Freud, Machado de Assis, Maquiavel e, se der sopa, até de Pôncio Pilatos, encadernações feitas na caverna de Ali Babá, vá lá os exageros.

Muitos bibliófilos milionários incorporaram essas ideias e não reconhecem o direito de concorrentes menos aquinhoados financeiramente possuírem bibliotecas tão boas ou melhores do que as suas. É o que aconteceu com este que vos fala. Ao saber que eu possuía um determinado livro, bastante raro, um senhor milionário, que todos aqui conhecem mas cujo nome não vou declinar, teve um acesso de despeito, bradando que a posse de tal preciosidade deveria ser reservada às pessoas etc., não preciso concluir. 
Pois bem, apesar desse senhor, a maioria dos bibliófilos são pessoas com algum poder aquisitivo, membros da classe média, mas que muitas vezes se privam de coisas essenciais ao cotidiano para adquirir uma peça rara. O mesmo ocorre com os seus concorrentes diretos, os bibliômanos. Em verdade, anseios e objetivos de ambos são bem semelhantes e as diferenças bastante sutis. Em geral, aponta-se como qualidades distintas do bibliófilo a sensibilidade, a inteligência e o bom gosto, mas o mesmo se aplica a muitos bibliômanos, como tenho constatado. Ambos têm o mesmo amor inquietante pelo livro, a compulsão em possuí-los, resultando na formação de conjuntos preciosos pela qualidade, pela quantidade ou por ambas. O que os distingue, a meu ver, é o uso que ambos fazem dos livros e a filosofia que orienta as suas coleções.

Os bibliófilos em geral formam a sua coleção obedecendo a um critério, centralizado em determinado assunto, o que não impede a diversificação de temas. Afinal, as áreas de conhecimentos estão muito próximas e por vezes intrincadas umas nas outras. Quem estuda literatura, se quiser ler em profundidade, tem de recorrer frequentemente não apenas a dicionários, mas também a manuais de história, geografia, sociologia etc. Além do mais, não é nenhum pecado o interesse por múltiplos assuntos. Além do mais, por que o apaixonado por história ou literatura, não pode ter também se interessar por astronomia? Ou mecânica? O fundamental é que os livros do bibliófilo se destinam ao estudo e ao prazer da leitura. O que não os impede, como pessoas de bom gosto, de se deliciarem com uma edição rara, um livro bem ilustrado, uma encadernação primorosa, uma dedicatória autografada. O requinte é inevitável no prazer bibliográfico, mas começa a degenerar quando passa a primeiro plano, sobrepondo-se à finalidade de estudo e prazer intelectual.

Já os bibliômanos juntam livros muitas vezes sem critério, apenas pelo prazer de posse, a raridade dos exemplares, a beleza das encadernações etc. O que, também, não é regra inflexível. Alguns se iniciam em tema de seu interesse, têm discernimento, mas são indiferentes ao conteúdo dos livros. Formam uma coleção capaz de disparar o coração de um bibliófilo, mas não se interessam em lê-los. Quando muito, consentem em exibi-los. Como aquele Cardeal da Cunha, de Portugal, dono de uma biblioteca de onze mil volumes que a malícia da época chamava de as onze mil virgens. Essa atitude não era novidade. Existia desde a Roma dos Césares despertando a revolta dos literatos pobres. Luciano de Samósata, autor do Diálogo dos Mortos, - de olho nas coleções de bibliófilos que não o admitiam em suas casas - comparava-os ao "cão que, deitado na estrebaria e não podendo comer a cevada, não permite que o cavalo a coma”. Em suma, de acordo com um estudioso 
Ramsés II, autor da mais antiga declaração de amor ao livro.

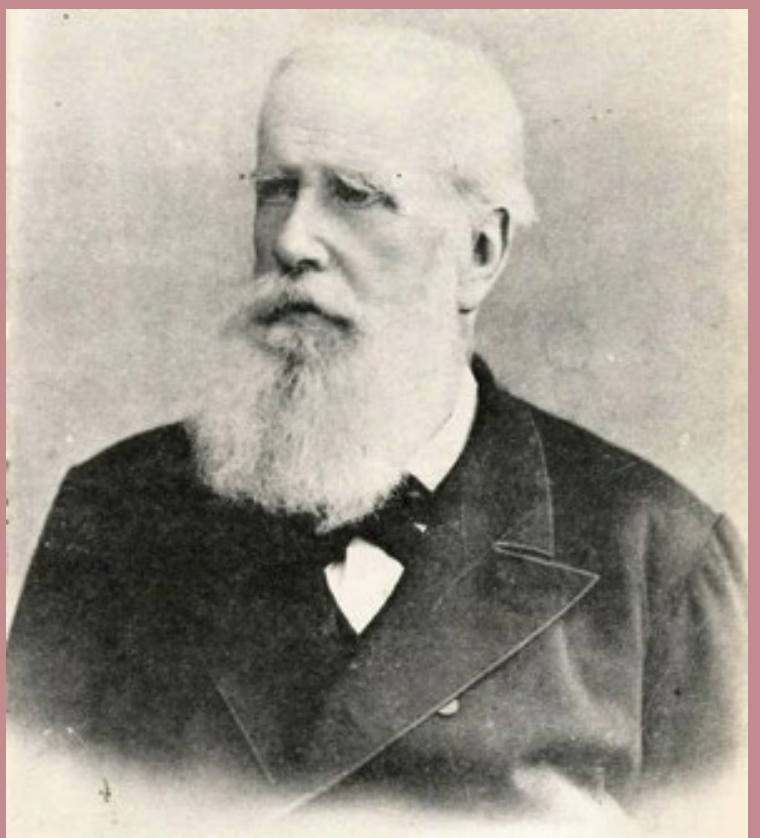

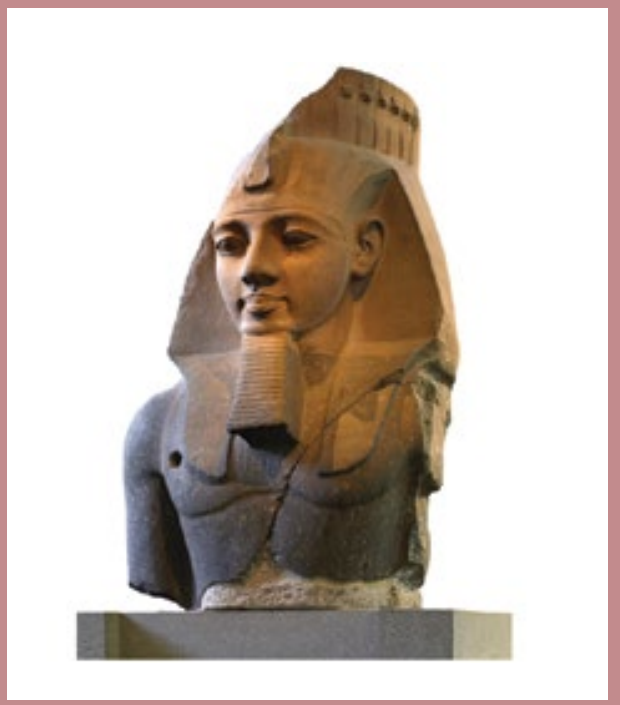

Dom Pedro II dizia amar os livros com os cinco sentidos. 
francês os bibliófilos possuem livros e os bibliômanos são possuídos pelos livros. Mas, tudo somado e batido em liquidificador, acho que todo bibliófilo tem o seu tanto de bibliômano. E, com vossa licença, vice-versa, o contrário.

Seja como for, ao longo dos séculos, quando se trata de chacotas aos colecionadores de livros, bibliófilos e bibliômanos costumam ser igualados. Anatole France, ele mesmo um refinadíssimo bibliófilo, misturou-os na mesma salada. "Tem-se troçado dos bibliófilos" - observa - “e talvez, afinal de contas, eles se prestem à zombaria: é o caso de todos os namorados... Julga-se confundi-los dizendo que eles não leem os seus livros". Mas um deles respondeu sem embaraço: "E vocês, será que comem na sua velha faiança?”, isto é, em suas porcelanas raras.

O egoísmo é uma acusação dirigida não apenas ao bibliófilo, mas a toda a categoria dos colecionadores. Essa alegação condenatória em geral parte daqueles que desejariam que os bens do mundo fossem comuns a todos, excetuados os seus bens privados, obviamente. Desde já podemos descartar tal acusação, lembrando que boa parte da memória humana e de sua riqueza cultural subsiste primeiro em coleções privadas, só mais tarde incorporadas - quando tal acontece - ao patrimônio público, museus e bibliotecas.

Entre zombarias e admirações, elogios e provocações, os bibliófilos vivem ameaçados por uma outra espécie de amante do livro, amante indigno, quase sempre sujeitos astuciosos, agradáveis e bons de lábia, os bibliopiratas, dispostos às atitudes mais ousadas para se apossar de um livro.

Numa categoria semelhante estão aqueles sujeitos capazes de se corromper para obter um exemplar desejado. A propósito, e em tom de blague, Jules Janin lembra o diálogo entre Pierre Séguier, chanceler de Luís XIII e dono de uma bela biblioteca, e este rei de França. Um dia, os dois conversavam tranquilamente quando o rei perguntou se ele, Séguier, seria capaz de vender a justiça e qual seria o seu preço.

- Oh sire, por nenhum preço... Mas, por um belo livro, não garanto...

Contam as línguas viperinas que até um homem escrupuloso como D. Pedro II, teria furtado um livro da biblioteca do Colégio de Caraça, em Minas Gerais, quando de sua visita àquela instituição. Tratar-se-ia da Crônica, de Eusébio Panfílio, bispo de Cesareia, editada em Veneza, em 1483. A história foi desmentida, talvez tenha sido uma simples calúnia de algum inimigo do monarca, sabendo a sua paixão livresca. O imperador dizia amar os livros com os cinco sentidos. Uma afirmação metafórica que não pode ser interpretada ao pé da letra. Amar os livros com a visão, o tato e o olfato, vá lá. São apreciações quase sensuais. A audição, gozar o ruído das folhas viradas de um livro, já é mais difícil. 
Mas, como incluir o paladar nesse amor? Será que o imperador lambia os livros ou comia as folhas, como se fossem uma alface apetitosa?

Com dois, três ou quatro sentidos em alerta, agrada-me mais, ver a bibliofilia - a autêntica, a do colecionador sensível e inteligente que compra os livros para serem lidos, estudados e consultados - como foi definida por José Mindlin: uma loucura mansa. Ressaltando que loucura aqui se aproxima muito mais do sentido erasmiano do termo - a loucura como oposta à mediocridade dos excessos de sensatez - do que do desequilíbrio que leva o cidadão ao hospício. Se todos somos loucos, como ironizava Erasmo, a exceção seria o sujeito incapaz de despropósitos, ou seja, a súmula da mediocridade. Por provocar a loucura é que, paradoxalmente, o contato dos livros é salutar. E a loucura mansa costuma levar ao que o mundo mais precisa: tolerância, simplicidade de espírito, respeito pelo semelhante.

Aproveitando a deixa da loucura mansa, gostaria de lembrar o lento processo de inoculação em mim desse veneno delicioso e minha perversão precoce como eterno aprendiz de bibliófilo, minhas aventuras bibliográficas e meu percurso como colecionador de livros. Em mais de sessenta anos de paixão constante reuni um acervo, e o digo sem falsa modéstia, de grande riqueza no que se refere sobretudo à literatura brasileira, à caricatura, e uma respeitável parte de literatura francesa.

Mas, minha livraria - e agrada-me empregar este velho termo para designar biblioteca -, minha livraria, não se restringe a estes temas, ela se caracteriza pela variedade temática e, aproveitando outra afirmativa de José Mindlin, pela indisciplina. Aliás, em matéria de bibliofilia, indisciplina equivale a sabedoria e até mesmo a disciplina. A subversão da semântica. O termo impondo-se por seu sentido oposto. A disciplina em seu sentido lato sufoca. Na minha caótica livraria a literatura convive com álbuns de caricatura, manuais de história e de erotismo, como cães, gatos e girafas vivendo no mesmo ambiente. Uma arca de Noé.

O início de tudo, porém, teve muito de loucura, mas nada de mansidão. Pode ser melhor comparado a um turbilhão. O impacto da leitura de livros, no garoto de doze para treze anos, até então leitor de histórias em quadrinhos, provocou um descalabro em sua mente. Meu pai havia deixado uma coleção de Humberto de Campos e o ilustre maranhense foi o primeiro Virgílio a conduzir o modesto Dante adolescente pelos infernos, purgatórios e paraísos da literatura. Essa leitura deu um nó na cabeça do menino, que sofreu uma amarga crise de pessimismo, incapaz de separar o fascínio proporcionado por aqueles textos do veneno sutil que deles escorria. O próprio Humberto reconhecia suas maldades. Em um trecho de seu Diário Secreto dizia que se tornara tão cruel 
que até quando elogiava alguém, o elogiado não sabia se lhe agradecia ou lhe dava um soco na cara. Essa predisposição à crítica impiedosa e até a difamação pura e simples se intensificou com a elefantíase, com a deformação de pés e mãos. O que serviu para essa deliciosa maldade: "Por que me incham os pés se, ao contrário de muitos de meus colegas, não escrevo com as patas?”

Ainda bem que o veneno destilado por esse sujeito sofrido, amargurado, que encucou o menino, logo encontrou o contraveneno, exatamente nos livros - similia similibis curantur, o semelhante cura o semelhante -, ao contato com outras personalidades e sensibilidades, revelando-lhe a diversidade dos caracteres humanos e, aos poucos, ensinando-lhe como deixar de ser um joguete de opiniões e impressões alheias. Em suma, despertando-lhe um incipiente senso crítico diante dos livros, do ser humano e da vida, aguçado com a descoberta de outro terrível demolidor, o iluminado Voltaire, que lhe deu um novo nó na cabeça, mas no sentido de ensinar a pensar, de lucidez e libertação. Aprendi a lição, sem lhe herdar o sarcasmo. Ainda bem.

Quando devorei toda a coleção de Humberto de Campos e comprei meu primeiro livro, foi movido exclusivamente pela paixão da leitura, a descoberta daquele mundo alucinante, que como toda alucinação, nos atordoa, mas também nos liberta da rotina e, no caso específico do livro, nos projeta no reino mágico de todas as possibilidades, sem fronteiras, desde a ascensão ao infinito à luz puríssima das estrelas, até as escabrosas revelações da maldade humana.

A partir daí tornei-me um leitor implacável, lembrando aquele personagem de Machado de Assis, que "lia de manhã, de tarde e de noite, ao almoço e ao jantar, antes de dormir, depois do banho, lia andando, lia parado, lia em casa e na chácara, lia antes de ler e depois de ler”. Não cheguei a tanto, mas, por certo, li com a mesma volúpia. Em verdade, eu não lia apenas, mas mergulhava dentro dos livros, convivia com os personagens e com tal exaltação que parecia que eles estavam ali no quarto, com suas paixões e desenganos, amores e rancores, ideais e frustrações. Terminada a leitura, ao me levantar da velha cadeira de balanço, tinha a sensação de esbarrar em vagas formas humanas e de sentir olhares misteriosos me espreitando.

Recentemente, descobri que a grande escritora chilena, Isabel Allende, viveu experiência semelhante em sua adolescência. Nesse livro extraordinário que se chama Paula, ela conta que, incitada pelo tio, se convencera "de que na escuridão os personagens abandonam as páginas e percorrem a casa”, "vagando pelos cômodos, revivendo as suas aventuras e paixões: piratas, cortesãs, bandidos, bruxas e donzelas", o que a assustava. 
Com os seus personagens saltando ou não de suas páginas, os livros começaram a se acumular nas improvisadas estantes. Nessa época em que comecei a frequentar livrarias, década de 1950, a oferta de livros era imensa e os preços bastante acessíveis. Nos balcões e prateleiras encontravam-se com facilidade edições do século XIX e XVIII, livros autografados, edições de grandes clássicos franceses, Voltaire, Chateaubriand, Victor Hugo. A fartura bibliográfica era uma tradição do Rio de Janeiro, que o digam os colecionadores paulistas que saíam daqui em caravana para comprar livros no Rio. As bibliotecas particulares eram enormes. A partir do processo de verticalização das residências, elas começaram a minguar. Com a escassez de espaço, moradores de casas imensas se mudavam para apartamentos e, muitos deles, se desfaziam de toda ou parte da biblioteca, por carência de espaço. O livreiro Carlos Ribeiro, já na década de 1970, comprava mais de quinhentos livros por dia.

Só mais tarde, com o amadurecimento do leitor no comércio de livros, as leituras, a conversa com colecionadores mais experientes, a formação de uma biblioteca especializada em literatura brasileira, agucei a sensibilidade para outras seduções do livro, a apresentação gráfica, o valor das ilustrações, a raridade das edições, o encanto de uma dedicatória e de um autógrafo, a harmonia de uma encadernação. É como começam todos os amores e todas as tentações. O aprendiz de bibliófilo passava a ter consciência do que sempre sentira de forma vaga, sem analisá-la. Pois em matéria de bibliofilia ninguém queima etapas. Bibliofilia é manifestação amadurecida do impulso pela leitura e do amor aos livros. Parodiando Machado de Assis - que dizia que o ladrão já nasce feito, a ocasião apenas o revela -, pode-se afirmar que o bibliófilo já nasce feito, as circunstâncias o revelam. E tais circunstâncias, em geral, só se impõem após um razoável amadurecimento. Ou, pelo menos, assim aconteceu comigo.

O primeiro fato digno de memória na aquisição de livros - quando o interesse pelo livro raro e bem editado começava a se impor - se deu aos dezoito, dezenove anos, na Livraria do Povo, de Antonio Severo Santana, o livreiro mais simpático da cidade. Risonho, malicioso, comentava os fatos com muita graça e uma pontinha de maldade, seguidos por uma risada estrepitosa. Generoso como poucos. Era a primeira vez que eu entrava naquela loja diminuta, na qual não cabiam mais de três pessoas enxutas. Se o freguês fosse gordo, o local comportava apenas duas. Fiquei estatelado. A loja estava repleta de preciosidades, primeiras edições de poetas românticos, simbolistas, parnasianos, modernistas, romances que eu nunca mais veria, revistas do século XIX, exemplares autografados, o diabo a quatro. Apesar de eu ser um desconhecido, o livreiro 


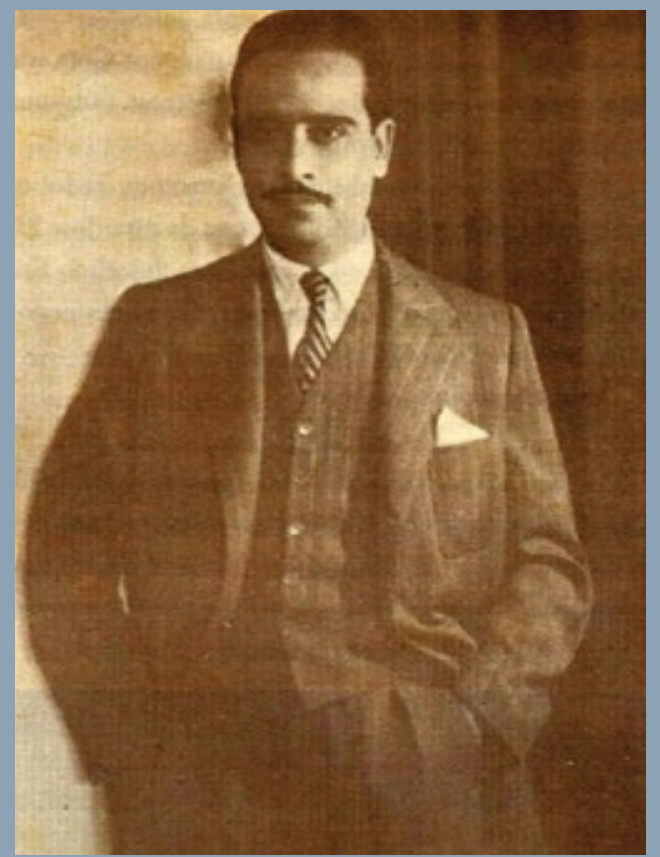

José e Guita Mindlin em sua residência. José Mindlin definiu o amor pelos livros como loucura mansa.
Na década de 1970, o livreiro carioca Carlos Ribeiro comprava quinhentos livros por dia.

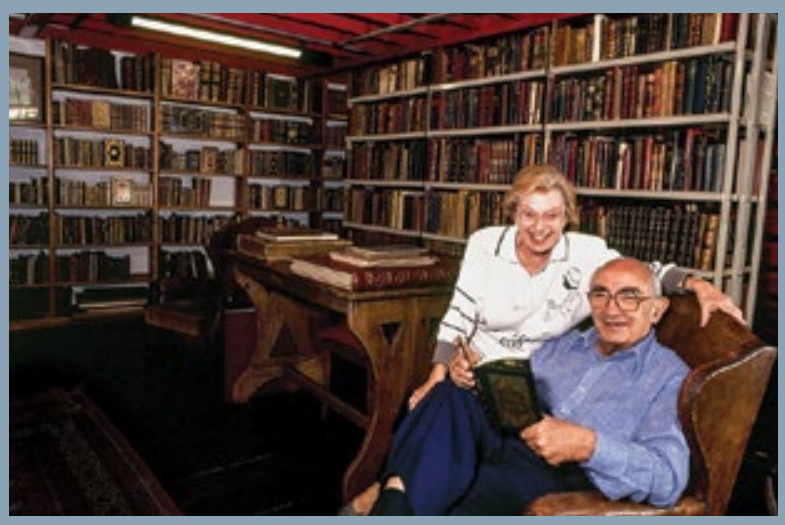


conversou comigo como se fôssemos velhos amigos. Fiquei sabendo que aquele material pertencia à biblioteca de Múcio Leão, recentemente falecido. Com gula de bibliófilo aprendiz, separei uma meia dúzia de livros. Como eram muito caros, me restringi a dois, um romance naturalista, não lembro qual, e um volume encadernado do Jornal das Famílias, de 1862, num estado miraculoso de conservação.

Pedi ao Santana que guardasse os livros por alguns dias. Para minha surpresa, ele os embrulhou - naquela época ainda não se usava saco plástico -, amarrou e colocou nas mãos do rapaz, que via pela primeira vez, dizendo com um sorriso nos lábios: "Leva, paga quando puder". Como esquecer um gesto deste?

Nem sempre era assim. Muitas livrarias estavam em mãos de analfabetos, incapazes de gentileza, mas também de avaliar o valor real de um livro. Acontecia, então, um fenômeno curioso. Ou cobravam um preço excessivo por livros que julgavam raros e que, muitas vezes, nada valiam, ou vendiam obras realmente raras por preço irrisório. Digo isso por experiência própria. Num sebo bastante modesto, descobri, no fundo da loja, numa prateleira junto ao chão, na seção de "Pássaros”, assunto que nunca me interessou, mas à qual fui guiado pela intuição, a coleção completa, 52 números, do raríssimo jornalzinho O Beija-Flor, editado por Joaquim Norberto, entre 1849 e 1852. Quase dei um pulo de alegria, e aquele beija-flor, vendido a preço de canário da terra, foi piar na minha biblioteca.

Por vezes, o amante de livros parece receber um presente dos céus, talvez de Santa Wilborada. Em certa ocasião, a Livraria Brasileira havia comprado uma grande biblioteca no interior do Estado. Muitos livros estavam em condição lastimável, mas havia preciosidades bem conservadas. Comprei uns cinco ou seis volumes. Chegando em casa, como minha mãe estava com visita, ao contrário de meus hábitos, deixei os livros embrulhados. Alguns dias depois, ao abri-los tive a surpresa maravilhosa: dentro de um deles encontrei um original de Di Cavalcanti. Um desenho a nanquim no verso do convite de sua última exposição em Paris.

Na faixa dos quarenta anos - já com um acervo respeitável de livros raros, autógrafos etc. -, deixei a revista onde exercia a função de redator e passei a trabalhar para uma empresa multinacional e, durante seis ou sete anos, viajei por todo o Brasil. Claro que, cumpridas as obrigações profissionais, era inevitável a excursão aos sebos da cidade. Descobri muita pepita em livrarias modestas do Pará, do Maranhão, de Santa Catarina, do Rio Grande do Sul. Aqui em São Paulo, eu vinha com alguma frequência desde os anos 1960. Comprei muita obra valiosa na Livraria Gazeau, na Praça da Sé, com seu fabuloso 
subterrâneo cheirando a mofo e repleto de raridades. Raras vezes paguei preço extorsivo por um livro. Raras, pois fui vencido algumas vezes. Mas, nunca me arrependi de comprar. Arrependimento só de não comprar. Como a primeira edição de Galinha Cega, de João Alphonsus, que encontrei numa feira do livro e esnobei. Quando me afastei, vi a imbecilidade que estava cometendo. Voltei à barraca, mas o livro já tinha sido vendido. Muitos anos depois, tentei cercar essa galinha, num leilão, mas ela fugiu para outras mãos. Ou como aquele livro de Manuel Bandeira com a deliciosa dedicatória a Luís da Câmara Cascudo: “Ao Luiz, com um cascudo do Manuel”.

Hoje, no crepúsculo da vida, inclino-me a admitir que o livro, além de ser o melhor amigo do homem, tem também vida própria. Os antigos comparavam-no a seres vivos, dotados de sensibilidade, caprichosos e originais. Concordo e acredito que eles, na ausência de seus donos, conversam entre si e até abandonam seu lugar na estante, cansados da posição vertical, para descansar, se deitando no chão e possivelmente até passeando pela casa. Talvez isso explique como certos livros desaparecem de nossas vistas, localizados mais tarde nos lugares mais improváveis, para onde nunca os levaríamos. Por vezes, tenho mesmo a impressão, ao sair de casa, de ouvir um confuso rumor de vozes tímidas, e ao abrir a porta de supetão me parece ver alguns livros pulando para seus lugares na estante. Pode ser ilusão, fantasia ou o agravamento daquela loucura mansa a que o Mindlin se referia, a qual, afinal de contas, vale todas as canseiras da vida.

\section{SOBRE 0 AUTOR}

Ubiratan Machado nasceu no Rio de Janeiro, em 1941. Jornalista, tradutor, tem mais de vinte livros publicados de ensaios, biografias e história, entre os quais Os Intelectuais e o Espiritismo, A Vida Literária no Brasil Durante o Romantismo, A Etiqueta de Livros no Brasil, Dicionário de Machado de Assis e História das Livrarias Cariocas. Em 2006, recebeu a medalha João Ribeiro, da Academia Brasileira de Letras, por serviços prestados à cultura brasileira, e em 2014 foi contemplado com o Prêmio Senador José Ermirio de Moraes, patrocinado pela Votorantim e escolhido pela Academia Brasileira de Letras como melhor livro do ano anterior. 


\section{RESUMOS E REFERĖNCIAS}

\section{DESCAMINHOS DO COLECIONISMO $p .19$}

RESUMO $O$ autor faz um percurso das pequenas aventuras para adquirir seus livros e de sua condição de aprendiz de bibliófilo, além de abordar alguns aspectos relacionados à bibliofilia - uns históricos e outros atuais - sendo que estes incomodam todos os amigos do livro.

BIBLIOFILIA • BIBLIÓFILOS • LIVROS RAROS • JOSÉ MINDLIN.

\section{MISADVENTURES OF THE ART} OF COLLECTING

ABSTRACT The author reflects over his path to acquire his books and his condition as a learner of the bibliophile trade. He also addresses a few aspects related to bibliophilia some historical and others from the present time - which troubled all the friends of the book.

BIBLIOPHILIA • BIBLIOPHILE • RARE BOOKS • JOSÉ MINDLIN. 